\title{
SEROPOSITIVITY FOR ASCARIOSIS AND TOXOCARIOSIS AND CYTOKINE EXPRESSION AMONG THE INDIGENOUS PEOPLE IN THE VENEZUELAN DELTA REGION
}

Zaida ARAUJO(1), Sietze BRANDES(2), Elena PINELli(2), María A. BOCHICHIO(1), Andrea PALACIOS(1), Albina WIDE(3), Bruno RIVAS-SANTIAGO(4) \& Juan Carlos JIMÉNEZ(5)

\begin{abstract}
SUMMARY
The present study aimed at measuring seropositivities for infection by Ascaris suum and Toxocara canis using the excretory/ secretory (E/S) antigens from Ascaris suum (AES) and Toxocara canis (TES) within an indigenous population. In addition, quantification of cytokine expressions in peripheral blood cells was determined. A total of 50 Warao indigenous were included; of which 43 were adults and seven children. In adults, $44.1 \%$ were seropositive for both parasites; whereas children had only seropositivity to one or the other helminth. For ascariosis, the percentage of AES seropositivity in adults and children was high; $23.3 \%$ and $57.1 \%$, respectively. While that for toxocariosis, the percentage of TES seropositivity in adults and children was low; 9.3\% and 14.3\%, respectively. The percentage of seronegativity was comparable for AES and TES antigens in adults (27.9\%) and children (28.6\%). When positive sera were analyzed by Western blotting technique using AES antigens; three bands of 97.2, 193.6 and 200.2 kDas were mostly recognized. When the TES antigens were used, nine major bands were mostly identified; 47.4, 52.2, 84.9, 98.2, 119.1, 131.3, 175.6, 184.4 and 193.6 kDas. Stool examinations showed that Blastocystis hominis, Hymenolepis nana and Entamoeba coli were the most commonly observed intestinal parasites. Quantification of cytokines IFN- $\gamma$, IL-2, IL-6, TGF- $\beta$, TNF- $\alpha$, IL-10 and IL-4 expressions showed that there was only a significant increased expression of IL-4 in indigenous with TES seropositivity $(p<0.002)$. Ascaris and Toxocara seropositivity was prevalent among Warao indigenous.
\end{abstract}

KEYWORDS: Zoonoses; Ascaris suum; Toxocara canis; Warao.

\section{INTRODUCTION}

Infections with gastrointestinal nematode parasites are widespread and contribute significantly to both morbidity and mortality among humans, and livestock in developing countries ${ }^{45}$. The most prevalent parasitic helminth in humans, Ascaris lumbricoides, is estimated to infect 1.5 billion people globally ${ }^{4}$. Toxocara canis and Ascaris suum are roundworms of dogs and pigs, respectively; these are the causative agents of important zoonoses such as toxocariosis and ascariosis ${ }^{2,4}$. Humans may accidentally become infected with $T$. canis or A. suum after ingestion of embryonated eggs present in soil contaminated with dog or pig feces or after consumption of infected raw or undercooked meat $^{2,45}$. In the accidental hosts, the $T$. canis larvae do not develop to the adult stage but persist in tissues as the larval stage for many years ${ }^{33,34}$. Once the infective eggs are ingested the larvae hatch, penetrate the small intestine and migrate to different tissues in the body inducing inflammatory responses. Migration of larvae can lead to a syndrome known as Visceral Larva Migrans (VLM). Symptoms of VLM include fever, hepatosplenomegaly and respiratory distress such as wheezing, coughing and episodic airflow obstruction ${ }^{34,38}$. Other symptoms include eosinophilic pneumonia (Loeffler's pneumonia) that bears a clinical resemblance to the pulmonary inflammatory responses observed in asthmatic patients. Immunological features of these zoonoses include eosinophilia and increased serum IgE levels $\mathrm{s}^{30,36,40}$.

Diagnosis of these zoonoses depends mostly on serological tests because the eggs are not passed in the feces of the host and biopsies to detect the larvae are usually negative ${ }^{11,12}$. Since the studies made by SAVIGNY ${ }^{37}$, the antigens mostly used for the immunodiagnostic tests are excreted products derived from larvae cultivated in vitro and are referred to as Toxocara excretory/secretory (TES) antigens ${ }^{35,37}$. Nematode excretory/secretory (E/S) antigens are not species or genus specific and serum samples from patients with ascariosis, filariosis and strongyloidiosis show cross-reactivity with ES from $T$. canis and A. suum antigens when using enzyme-linked immune assay (ELISA), immunoprecipitation and Western blotting $3,5,18,20,21,29,37$. A major concern is the specificity of the ELISA and WB diagnosis of T. canis and A. suum in areas where gastrointestinal nematode infections of humans also exist. In this context, in most areas in which A. lumbricoides is endemic, which is a common intestinal nematode of children, exposure to A. suum and 


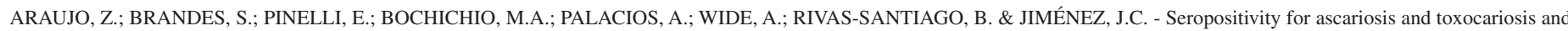
cytokine expression among the indigenous people in the Venezuelan Delta region.. Rev. Inst. Med. Trop. Sao Paulo, 57(1): 47-55, 2015.

T. canis is likely to be sufficiently common to confuse serodiagnosis. In Venezuela, diagnosis of zoonotic infections with A. suum and T. canis is routinely made by ELISA after absorption of serum samples with $A$. lumbricoides antigens, a nematode antigenically related with A. suum and $T$. canis $^{6,22}$.

Although parasitic helminth infections generally do not lead to mortality; chronic infections can lead to considerable morbidity ${ }^{25,31}$. Chronic helminth infections are characterized by skewing towards a $\mathrm{T}$ helper 2 type response as well as regulatory responses ${ }^{8,43}$. The regulatory network is thought to prevent strong immune responses against parasitic worms, allowing their long-term survival and restricting pathology. A number of parasitic nematodes have also been reported to exert potent immunomodulatory effects also suppressing immune responses to non-parasite antigens and to other infectious agents in a nonspecific manner ${ }^{30,41}$. PATERSON et al. have reported that the body fluid from the adult Ascaris suum (ABF) has potent immunomodulatory activity and that the effects observed are consistent with skewing towards Th2-type response $^{32,40}$. In addition, the induction of interleukin- 10 by $\mathrm{ABF}$ also suggests that $\mathrm{T}$ regulatory cells may play a role in immunomodulation of immune responses by parasitic helminths ${ }^{32}$.

The present study aimed to measure anti-Ascaris suum and antiToxocara canis antibodies in sera through ELISA and Western blotting techniques. In addition parasitological examination from stool samples and the cytokine gene expression of pro-inflammatory and Th1/Th2-type cytokines in blood of Warao indigenous, a population that live closely with pigs and dogs, were performed.

\section{MATERIALS AND METHODS}

The study was conducted in Warao indigenous communities from the Antonio Díaz and Pedernales municipalities, in the Venezuelan Delta, two parasitic-endemic rural regions of the Delta Amacuro State. The Warao indigenous communities are settled in remote rural areas. The houses are constructed on wooden stilts on the River Orinoco. Most inhabitants do not have access to reliable potable water for drinking nor adequate sanitation systems. Within this indigenous population is not easy to carry out research projects because invasive procedures cannot be used to take samples due to ethical considerations. Adults and children aged 15 to 70 and four to 14, respectively, were studied, of whom according to ELISA reactivity were grouped as: 1) Sera positive for the excretory/secretory (E/S) antigens of Ascaris suum (AES), 2) Sera positive for the E/S antigens of Toxocara canis (TES), 3) Sera positive for both, AES and TES antigens and 4) Sera negative for both AES and TES antigens which were used as a negative reference (control group).

Blood samples were collected in vacutainers with and without EDTA as anticoagulant. Serum was separated and stored at $-20{ }^{\circ} \mathrm{C}$ until use. Individuals were included in the study taking into account inclusion and non inclusion criteria. Inclusion criteria: 1) The volunteers are healthy individuals without evidence of clinical symptoms suggesting pulmonary infection. Non inclusion criteria: 1) Individuals who were HIV positive, 2) Patients taking immunosuppressive drugs (e.g., corticosteroids, azathioprine and cyclophosphamide), 3) Participants who did not sign an informed consent agreement. This study was approved by the Ethical Committee of the Biomedicine Institute (protocol number PG-
09-8007/2011). All the inhabitants who participated were included after obtaining a free and informed consent statement from them.

The excretory-secretory (E/S) antigen derived from Toxocara canis and Ascaris suum was prepared as previously described ${ }^{33}$. Briefly, adults of $T$. canis and A. suum worms were collected from the feces of naturally infected dogs and pigs, after routine deworming using antihelminthic treatment. Eggs were collected from the uteri of female worms and were allowed to embryonate in $0.05 \mathrm{M} \mathrm{H} 2 \mathrm{SO} 4$ in the dark at room temperature for 4-6 weeks. Embryonated eggs were stored in $0.05 \mathrm{M} \mathrm{H} 2 \mathrm{SO} 4$ at $4{ }^{\circ} \mathrm{C}$ until use. Larvae were freed from the egg shells and allowed to migrate through cotton wool contained in Pasteur pipettes that were placed in tubes filled with medium at $37^{\circ} \mathrm{C}$ overnight. The migrating larvae were collected and counted. A suspension of 150 larvae per $\mathrm{mL}$ medium was incubated at $37{ }^{\circ} \mathrm{C}$. Fresh medium was added and after a week, the harvested medium was used as the E/S antigens.

Detection of anti-Toxocara and anti-Ascaris IgG antibodies was performed using an ELISA and the excretory/secretory (E/S) antigens derived either from $T$. canis or A. suum larvae as previously reported ${ }^{33}$. Medium binding ELISA microtiter plates (Nunc, Roskilde, Denmark) were used for the Toxocara ELISA and high binding plates (Greiner, Frickenhausen, Germany) were used for the Ascaris ELISA. The plates were coated with E/S antigens $(10 \mu \mathrm{g} / \mathrm{mL})$ diluted in $0.1 \mathrm{M}$ sodium carbonate (Na2CO3), $\mathrm{pH}$ 9.6. The plates were incubated overnight (without lids) at $37^{\circ} \mathrm{C}$ to allow the E/S antigens to dry onto the wells. They were then washed three times with phosphate-buffered saline ( $\mathrm{pH}$ 7.2) containing $0.05 \% \mathrm{v} / \mathrm{v}$ Tween-20 (PBS/Tween). For the Ascaris ELISA an additional blocking step was performed by adding $2 \%$ bovine serum albumin (BSA) (Boehringer Mannheim, GmbH, Germany) solution in PBS/Tween to every well. The plates were incubated for $30 \mathrm{~min}$ at $37^{\circ} \mathrm{C}$ and thereafter washed three times with PBS/Tween. Serum samples were diluted 1:40 in $2 \% \mathrm{BSA} / \mathrm{PBS} / \mathrm{Tw} w e e n$ and added to the plates. After one hour incubation at $37^{\circ} \mathrm{C}$, the plates were washed and anti-human IgG conjugated to alkaline phosphatase (DAKO, Glostrup, Denmark) diluted in 4\% BSA/PBS/Tween was added for one hour at $37^{\circ} \mathrm{C}$. After the plates were washed, substrate, $\mathrm{H}_{2} \mathrm{O}_{2}, 0.05 \%$ and 5-ASA was added for one hour at room temperature after which the absorbance was read at $450 \mathrm{~nm}$. The extinction value of the tested serum and of the cut-off serum was used to calculate a ratio. A ratio higher or equal to 1.0 was considered positive. The cut-off value was defined as the mean absorbance of 20 serum samples from healthy blood donors plus three times the standard deviation ${ }^{33}$.

Electrophoresis procedure was performed; TES and AES antigens were fractionated by polyacrylamide gel electrophoresis with dodecil sulfate (SDS-PAGE) according to LAEMMLI ${ }^{17} 10 \%$ running gel and a $4 \%$ acrylamide stacking gel were used. $1.2 \mu \mathrm{g}$ of TES or AES antigens was mixed with sample buffer (Tris $0.5 \mathrm{M}$, pH 6.8; $10 \%$ SDS, $0.4 \mathrm{~mL}$ of 2-mercaptoethanol, $0.3 \%$ bromophenol blue, $2 \mathrm{~mL}$ of glycerol) for one min and applied to a polyacrylamide gel. The sample was electrophoresed with constant voltage $(100 \mathrm{~V})$ until bromophenol blue had entered the running gel when it was increased to $120 \mathrm{~V}$. Transfer buffer, $\mathrm{pH} 8.3$, contained three $\mathrm{g}$ of Tris base, $14.4 \mathrm{~g}$ of glycine and one $\mathrm{g}$ of SDS. Molecular weight standards (Sigma SDS-200) were included to calculate molecular weights.

Transfer was performed according to TOWBIN et al. ${ }^{42}$ in a Miniprotean II cell (Bio-Rad Laboratories, CS, US) using 180 mAmp 


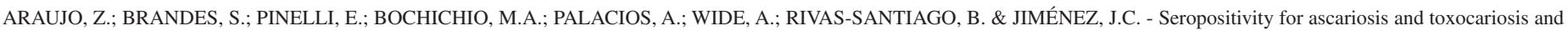
cytokine expression among the indigenous people in the Venezuelan Delta region.. Rev. Inst. Med. Trop. Sao Paulo, 57(1): 47-55, 2015.

applied over two hours to a nitrocellulose membrane in transfer buffer. Nitrocellulose strips containing transferred proteins were rinsed with PBS and incubated for one hour with PBS-Tween and 5\% skimmed milk to block remaining free sites and test sera diluted 1:100 overnight. Following three washes with PBS-Tween to remove unbound antibody, strips were incubated for one hour in anti-human IgG conjugated with peroxidase diluted 1:2000 (Vector lab, Inc). After three washes with PBS-Tween and $5 \%$ skimmed milk, TMB substrate KIT containing two drops of buffer stock solution, three drops of tetramethylbenzidine (TMB), two drops of stabilization solution and two drops of hydrogen peroxide was added and bands were visible within 5-15 min (peroxidase substrate kit TMB SK-4400, Vector lab., Inc). To prevent cross-reactions, sera tested in the Toxocara-ELISA and Ascaris-ELISA were pre-absorbed with A. suum or A. lumbricoides extracts diluted 1:50 in PBS with 5\% skimmed milk, at room temperature.

For coproparasitological tests, two stool samples per individual were taken and collected fresh or preserved in Railliet-Henry solution at room temperature. Stool samples collected were analyzed using the gravitational sedimentation, Kato-Katz techniques and two fecal smears per individual were analyzed by direct microscopic observation to detect eggs of helminth and also protozoan cysts. The results of the stool examinations were provided to patients and the parents, and appropriate treatment for parasite infections was given.

As regards relative quantification of cytokine expressions, total RNA was extracted from peripheral blood cells by using a Total RNA Isolation System kit (Promega Corporation, WI, US) following the instructions of the supplier, and the RNA content was measured in a spectrophotometer at $260 \mathrm{~nm}$. cDNA was made from five micrograms RNA using a Reverses Transcription System kit (Promega Corporation, WI US). The RNA was incubated with a one $\mu \mathrm{L}$ of oligo dT primer $(50 \mu \mathrm{M})$, made up to $12 \mu \mathrm{L}$ with sterile and RNaseOut-free water, and incubated at $70{ }^{\circ} \mathrm{C}$ for $10 \mathrm{~min}$, after which it was quickly cooled on ice. A total of two $\mu \mathrm{L} \mathrm{10X} \mathrm{first-strand} \mathrm{buffer} \mathrm{(100} \mathrm{mMTris-HCl,} \mathrm{pH} 8.8$ at $25{ }^{\circ} \mathrm{C} ; 500 \mathrm{mMKCl} ; 1 \%$ Triton $\left.\mathrm{X}-100\right)$, two $\mu \mathrm{L} \mathrm{MgCl}_{2}(25 \mathrm{mM})$, two $\mu \mathrm{L}$ deoxynucleoside trisphosphate mix (10 mM of each dATP, dGTP, $\mathrm{dCTP}$ and dTTP) and one $\mu \mathrm{L}$ of RNaseOutRNase inhibitor (40 U/ $\mu \mathrm{L}$ ) were added. The mix was incubated at $42{ }^{\circ} \mathrm{C}$ for two min after which it was further incubated at $42{ }^{\circ} \mathrm{C}$ for $50 \mathrm{~min}$ and $70^{\circ} \mathrm{C}$ for $10 \mathrm{~min}$ with one $\mu \mathrm{L}$ of AMV Reverse Transcriptase. The cDNA content was measured in a spectrophotometer at 280/260 $\mathrm{nm}$. The cDNA samples were stored at $-80{ }^{\circ} \mathrm{C}$ until use.

Reverse Transcriptase-Polymerase Chain Reaction (RT-PCR) was performed, 25 nanograms of cDNA generate as above was amplified and made up to $10.5 \mu \mathrm{L}$ with sterile and nuclease-free water. Twelve and a half $\mu \mathrm{L}$ of the master-mix containing the PCR buffer ( $50 \mathrm{mMTris}-\mathrm{HCl}$, $\mathrm{pH} 9 ; 50 \mathrm{mMNaCl} ; 5 \mathrm{mM} \mathrm{MgCl} ; 200 \mu \mathrm{M}$ of each deoxynucleoside trisphosphate, dATP, dGTP, dCTP and dTTP) and the Taq DNA polymerase $(50 \mathrm{U} / \mu \mathrm{L})$ and one $\mu \mathrm{L}$ of each primer (five $\mathrm{mM}$ ) was added in a final volume of $25 \mu \mathrm{L}$. Sequences of the used primer pair are shown in Figure 1. Mixtures with cDNA were placed in a MJ mini Personal Thermal Cycler (BioRad Laboratories, CA, US) preheated to $95^{\circ} \mathrm{C}$ for $10 \mathrm{~min}$. Cycling parameters were 40 cycles of denaturation at $95^{\circ} \mathrm{C}$ for $15 \mathrm{sec}$, annealing at $60^{\circ} \mathrm{C}$ for one min, extension at $70^{\circ} \mathrm{C}$ for one min and a final extension for seven min at $72{ }^{\circ} \mathrm{C}$. For IL-2 and $\beta$-actin the annealing was carried out at $58{ }^{\circ} \mathrm{C}$ and $55^{\circ} \mathrm{C}$ respectively. Amplified products were separated by $2 \%$ agarose gel electrophoresis, stained with SYBR Green I (Sigma-Aldrich Co, St. Louis MO, US) and visualized by a Benchtop UV transilluminator, MultiDoc-It Digital Imaging System camera combination.

\begin{tabular}{|l|l|}
\hline IL-2 & $\begin{array}{l}\text { Forward: 5'-AAGTTTTACATGCCCAAGAAGG-3' } \\
\text { Reverse: 5'-AAGTGAAGTTTTTGCTTTGAGC-3' }\end{array}$ \\
\hline IL-4 & $\begin{array}{l}\text { Forward: 5'-CACCGAGTTGACCGTAACAG-3' } \\
\text { Reverse: 5'-GCCCTGCAGAAGGTTTCC-3' }\end{array}$ \\
\hline IL-6 & $\begin{array}{l}\text { Forward, 5'-ATGTAGCCGCCCACACAGA-3' } \\
\text { Reverse, 5'-CATCCATCTTTTTCAGCCAT-3' }\end{array}$ \\
\hline IL-10 & $\begin{array}{l}\text { Forward, 5'-ACAGGGAAGAAATCGATGACA-3' } \\
\text { Reverse, 5'-TGGGGGAGAACCTGAAGAC-3' }\end{array}$ \\
\hline IL-12p35 & $\begin{array}{l}\text { Forward, 5'-CACTCCCAAAACCTGCTGAG-3' } \\
\text { Reverse, 5'-TCTCTTCAGAAGTGCAAGGGTA-3' }\end{array}$ \\
\hline IFN- $\gamma$ & $\begin{array}{l}\text { Forward, 5'-TTTGGATGCTCTGGTCATCTT-3' } \\
\text { Reverse, 5'-TTTGGATGCTCTGGTCATCTT-3' }\end{array}$ \\
\hline TGF- $\beta$ & $\begin{array}{l}\text { Forward, 5'-CAGCCGGTTGCTGAGGTA-3' } \\
\text { Reverse, 5'-GCAGCACGTGGAGCTGTA-3' }\end{array}$ \\
\hline TNF- $\alpha$ & $\begin{array}{l}\text { Forward, 5'-GCCAGAGGGCTGATTAGAGA-3' } \\
\text { Reverse, 5'-CAGCCTCTTCTCCTTCCTGAT-3' }\end{array}$ \\
\hline$\beta$-actin & $\begin{array}{l}\text { Forward, 5'-GTGGGGCGCCCCAGGCACCA-3' } \\
\text { Reverse, 5'-CTCCTTAATGTCACGCACGATTTC-3' }\end{array}$ \\
\hline
\end{tabular}

Fig. 1 - Primers sequences. The following primer pairs were used: IL-2, IL-4, IL-6, IL-10, IL-12p35, IFN- $\gamma$, TGF- $\beta$, TNF- $\alpha$ and $\beta$-actin as internal control.

Statistical analysis was carried out using the software Epi-Info 6.0. Chi-square test was used to compare the significance of the differences according to the percentage values of seropositivities for infection by Ascaris suum (AES) and Toxocara canis (TES). A logistical regression method was used to compare independent variables including cytokine expression in peripheral blood cells from Warao indigenous with or without antibodies against the AES and TES antigens. A probability value $p<0.05$ was considered statistically significant.

\section{RESULTS}

Study population. Forty three adults aged $40 \pm 16$ years old $(25$ females and 18 males) and seven children aged $9 \pm 2.6$ years old (four females and three males) were studied (data not shown).

Comparable seropositivity for ascariosis and toxocariasis. The percentage of individuals with AES and TES seropositivity is shown in Table 1. Findings indicate that in adults, 19/43 (44.1\%) were seropositive for both parasites, whereas children had only seropositivity for one or the other helminth, $0 / 7(0 \%)$, there was significant difference between adult and children groups, $p<0.03$ (Table 1). For ascariosis, the percentage of AES seropositivity in adults and children was 10/43 (23.3\%) and $4 / 7(57.1 \%)$, respectively (Table 1$)$. While that for toxocariasis, the percentage of TES seropositivity in adults and children was low; 4/43 $(9.3 \%)$ and $1 / 7(14.3 \%)$, respectively, there was no significant difference among groups. The percentage of seronegativity was comparable for AES and TES antigens in adults 12/43 (27.9\%) and children 2/7 (28.6\%) (Table 1). 
ARAUJO, Z.; BRANDES, S.; PINELLI, E.; BOCHICHIO, M.A.; PALACIOS, A.; WIDE, A.; RIVAS-SANTIAGO, B. \& JIMÉNEZ, J.C. - Seropositivity for ascariosis and toxocariosis and cytokine expression among the indigenous people in the Venezuelan Delta region.. Rev. Inst. Med. Trop. Sao Paulo, 57(1): 47-55, 2015.

Table 1

Comparable seropositivity for Toxocara canis and Ascaris suum

\begin{tabular}{lcccc}
\hline Marker & $\begin{array}{c}\text { A. suum } \\
\text { Positive }\end{array}$ & $\begin{array}{c}\text { T. canis } \\
\text { Positive }\end{array}$ & $\begin{array}{c}\text { A.suum/T. canis } \\
\text { Positive }\end{array}$ & $\begin{array}{c}\text { A.suum/T. canis } \\
\text { Negative }\end{array}$ \\
\hline Female (\%) & 57.1 & 20.0 & 42.1 & $80.0^{(\mathrm{c})}$ \\
Male (\%) & 42.9 & 80.0 & 57.9 & $20.0^{(\mathrm{d})}$ \\
Adults (\%) & 23.3 & 9.3 & $44.1^{(\mathrm{a})}$ & 27.9 \\
Children (\%) & 57.1 & 14.3 & $0^{(\mathrm{b})}$ & 28.6 \\
\hline
\end{tabular}

For the AES and TES seropositivity group there was significant difference between (a) and (b), $p<0.03$. Within the seronegativity group there was significant difference between females (c) and males (d), $p<0.002$.

Gender difference in ascariosis and toxocariosis. When the possible gender effect on seropositivity for A. suum and T. canis was analyzed, findings showed that gender has no influence on either AES seropositivity; $8 / 14(57.1 \%)$ and $6 / 14(42.9 \%)$ for females and males, respectively, or AES/TES seropositivity; 8/19 (42.1\%) and 11/19 $(57.9 \%)$ for females and males, respectively (Table 1$)$. In contrast, a high percentage of males showed TES seropositivity $4 / 5(80.0 \%)$ as compared to females $1 / 5(20.0 \%)$, there was not a significant difference, probably due to the low number of individuals that composed these groups (Table 1). Within the seronegative group there was a significant difference between females $12 / 15(80.0 \%)$ and males $3 / 15(20.0 \%), p$ $<0.002$ (Table 1).

Age distribution and seropositivity for Ascaris and Toxocara. The possible age effect on seropositivity for A. suum and T. canis was also analyzed. The distribution of the age group was: 0-10, 11-20, 21-40 and 41-60 years old and the age group of 61 years and older. The percentage of A. suum seropositivity ranged from $7.7 \%$ for the age group of $0-10$ years old to $30.8 \%$ for the age group of 21-40 years old. The latter showed a higher percentage of $A$. suum seropositivity statistically significant as compared to the age groups of $0-10(7.7 \%), 11-20(10.3 \%)$ years old and 61 years and older $(7.9 \%), 0.01<p<0.04$. There was no significant difference between the age groups of 21-40 (30.8\%) and 41-60 (17.9\%) years old (data not shown).

The percentage of $T$. canis seropositivity ranged from $2.6 \%$ for the age group 0-10 years old to $25.6 \%$ for the age group of 21-40 years old. The latter showed a higher percentage of T. canis seropositivity statistically significant as compared to the age groups of 0-10 (2.6\%), $11-20(5.1 \%)$ years old and the age group of $61(6.7 \%)$ years and older, $0.006<p<0.02$. There was no significant difference between the age groups of $21-40(25.6 \%)$ and $41-60(10.3 \%)$ years old. The seropositivity thereafter clearly decreases for the age group of 61 years and older (data not shown).

Western blotting and band patterns. In order to identify the pattern of bands displayed by sera from Warao; AES and TES antigens were analyzed by Western blotting technique. For $A$. suum, the immunoblotting showed a pattern of bands ranging from 52 to $206.9 \mathrm{kDas}, 12$ bands of 206.9, 200.2, 193.6, 149, 114.6, 97.2, 94.1, 82.5, 67.8, 65.6, 55.6 and 52.2, kDas from A. suum were detected; of these, three bands of $193.6 \mathrm{kDa}$ (33.3\%), 200.2 kDa and 97.2 kDa (22.2\%) were principally recognized. Sera from healthy individuals did not show any IgG reactivity (data not shown). Western blotting procedures showing the obtained bands and the WB profile according to AES seropositivity are shown in Figure 2. Western blotting analysis using AES antigens showed the AES pattern composed by bands ranging from $52 \mathrm{kDa}$ to $206.9 \mathrm{kDa}$ (some of the most frequently recognized bands are shown in Figure 2A). The WB profile could be divided in the following groups according IgG reactivity to AES antigens; the group composed of bands between $50 \mathrm{kDa}$ and 100 $\mathrm{kDa}$ was the most reactive (50\%), followed by $151-207 \mathrm{kDas}(37.5 \%)$ and 101-150 kDas (12.5\%) (Fig. 2B).

As regards $T$. canis, the immunoblotting showed a pattern of bands,


Fig. 2 - Western blotting of Ascaris suum antigens. Western blotting procedures showing some of the most frequently recognized bands obtained according to AES seropositivity (2A). Tested sera were assayed in order to identify the bands of A. suum. WM: Molecular weight marker (2A). Percentage of individuals who composed the groups of bands according to anti-AES IgG antibodies (2B): Group of bands lower than $50 \mathrm{kDa}(\boldsymbol{\square})$, group of bands between 50 and $100 \mathrm{kDa}(\square)$, group of bands between $101-150 \mathrm{kDa}(\square)$, and group of bands between 151- $207 \mathrm{kDa}(\#)$ 


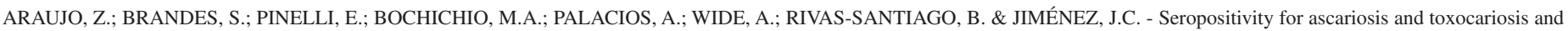
cytokine expression among the indigenous people in the Venezuelan Delta region.. Rev. Inst. Med. Trop. Sao Paulo, 57(1): 47-55, 2015.

which was ranging from $22.9 \mathrm{kDa}$ to $223 \mathrm{kDas}$; among these 11 major bands were principally identified; $84.9 \mathrm{kDa}(37.7 \%), 52.2 \mathrm{kDa}(33.3 \%)$, $131.3 \mathrm{kDa}(31.1 \%), 98.2 \mathrm{kDa}(28.8 \%), 119.1 \mathrm{kDa}(26.6 \%), 41 \mathrm{kDa}$ (26.2\%), $184.4 \mathrm{kDa}(24.4 \%), 175.6$ and $47.4 \mathrm{kDas}(22.2 \%), 193.6 \mathrm{kDa}$ $(15.5 \%)$ and $50 \mathrm{kDa}(11.9 \%)$. Sera from healthy individuals did not show any reactivity (data not shown). Western blotting procedures showing the obtained bands and the WB profile according to TES seropositivity are shown in Figure 3. Western blotting analysis using TES antigens showed the TES pattern composed by bands ranging from $22.9 \mathrm{kDa}$ to $223 \mathrm{kDa}$ (some of the most frequently recognized bands are shown in Figure 3A). The WB profile according to TES seropositivity could be divided into the following groups: the group composed of bands lower than $50 \mathrm{kDa}$ $(42.1 \%)$ was the most reactive; followed by the group of bands between $50 \mathrm{kDa}$ and $100 \mathrm{kDa}(28 \%), 151 \mathrm{kDa}$ and $207 \mathrm{kDa}(18.4 \%)$ and 101-150 kDas (11.4\%) (Fig. 3B).

Coproparasitological tests and intestinal parasites. The stool examinations showed that intestinal parasites are significantly frequent among Warao indigenous. Among these, protozoas (80.0\%) were more frequent than helminths (20.0\%). For the children group; Blastocystis hominis and Iodamoeba butschlii were the most prevalent parasites (85.7\%), followed by Entamoeba coli (71.4\%), Entamoeba histolytica and Hymenolepis nana (28.5\%) and Giardia duodenalis, Trichuris trichiura and Ascaris lumbricoides (14.2\%). For the adult group; E. coli was the most prevalent parasite (35.8\%), followed by B. hominis $(28.3 \%)$, I. butschlii (10.8\%), Endolimax nana (7.4\%), H. nana and T. trichiura (4.4\%), Chilomastix mesnili (2.1\%) and Ascaris lumbricoides (1.5\%).

Cytokine expressions and seropositivity for Ascaris and Toxocara. Figure 4 shows the cytokine expressions when RT-PCR assays were used for the relative quantification of mRNA encoding for IL-2, IL-4, IL-6, IL-10, IL-12p35 (Fig. 4A), and IFN- $\gamma$, TGF- $\beta$ and TNF- $\alpha$ (Fig. 4B) in peripheral blood cells from Warao indigenous. Results indicated that the largest expression of transcript was for IFN- $\gamma(100 \%)$ followed by TNF- $\alpha$ (90\%), IL-2 (85\%), IL-4 (67.5\%), IL-12p35 (55\%), TGF- $\beta$ (50\%), IL-6 and IL-10 (17.5\%) (Fig. 5). When a logistic regression method was used to compare independent variables including cytokine expression in peripheral blood cells from Warao indigenous that had or did not have antibodies against the AES and TES antigens showed that there was only a significant increased expression of the IL-4 in individuals with TES seropositivity $(p<0.002)$, whereas, the expression of all cytokines transcripts were not different to that of individuals with AES seropositivity (Fig. 5).

\section{DISCUSSION}

A preliminary assessment of zoonotic helminths such as A. suum and $T$. canis among Warao indigenous offered an opportunity to study these two zoonotic infections, namely ascariosis and toxocariosis in some communities that live closely with pigs and dogs. During infection with $A$. suum and T. canis, both cellular and humoral immune responses develop. In humans, several studies on the epidemiology, pathology and diagnosis of toxocariasis are available $e^{6,11,28,41}$ however, much less is known about human infections with $A$. suum. Few studies have reported on Ascaris suum being able to mature to the adult stage in the human host $^{31,38}$. NEJSUM et al. refer to this infection as zoonotic ascariasis and have recently reported that $A$. suum can also mature to the adult stages in chimpanzees ${ }^{28}$. There are however other studies reporting VLM cases

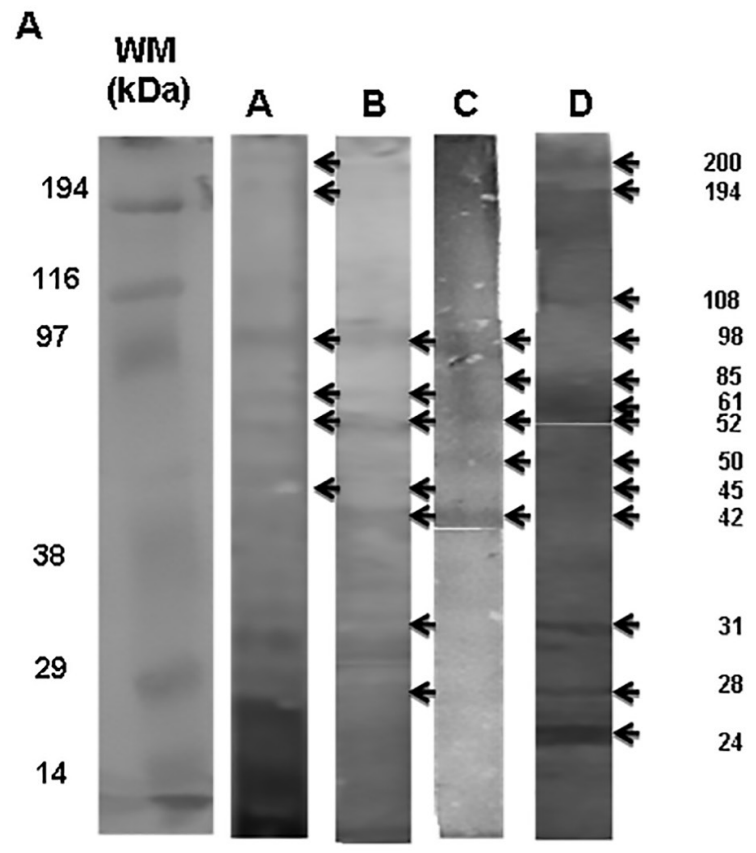

B

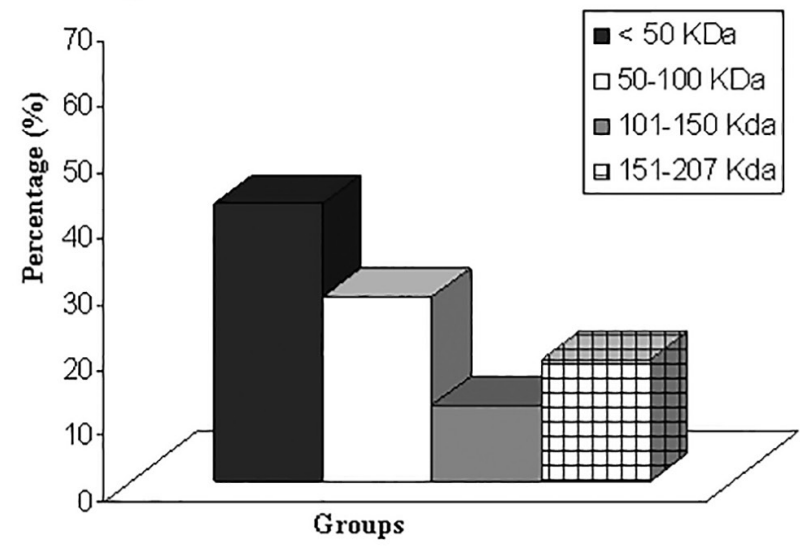

Fig. 3 - Western blotting of Toxocara canis antigens. Western blotting procedures showing some of the most frequently obtained bands according to TES seropositivity (3A). Tested sera were assayed in order to identify the bands of T. canis. WM: Molecular weight marker. Band (3A). Percentage of individuals who composed the groups according to anti-TES IgG antibodies (3B): Group of bands lower than $50 \mathrm{kDa}(\square)$, group of bands between 50 and $100 \mathrm{kDa}(\square)$, group of bands between $101-150 \mathrm{kDa}(\square)$, and group of bands between 151- $207 \mathrm{kDa}(\#)$.

that are suspected to be caused by Ascaris suum in which pulmonary and liver lesions have been described ${ }^{31}$. As suggested by ARIZONO et al. the pathogenic or physiogenetic factors that determine the course of human infection with pig-derived Ascaris remain to be elucidated ${ }^{2}$. In the present study, seropositivity associated with ascariasis and toxocariasis using the indirect-ELISA IgG was evidenced. The findings indicated that both adults and children showed high AES seropositivity, 23.3\% and $57.1 \%$, respectively as compared to TES seropositivity, $9.3 \%$ and $14.3 \%$, respectively. In the past, antigenic preparations of $T$. canis adults or larvae were used for the immunodiagnosis of toxocariosis ${ }^{24,39}$; however 
ARAUJO, Z.; BRANDES, S.; PINELLI, E.; BOCHICHIO, M.A.; PALACIOS, A.; WIDE, A.; RIVAS-SANTIAGO, B. \& JIMÉNEZ, J.C. - Seropositivity for ascariosis and toxocariosis and cytokine expression among the indigenous people in the Venezuelan Delta region.. Rev. Inst. Med. Trop. Sao Paulo, 57(1): 47-55, 2015.

the latter was improved by SAVIGNY, who obtained secreted antigens called Toxocara excretory-secretory antigens (TES-Ag) and used them together with ELISA (TES-ELISA) ${ }^{37}$.
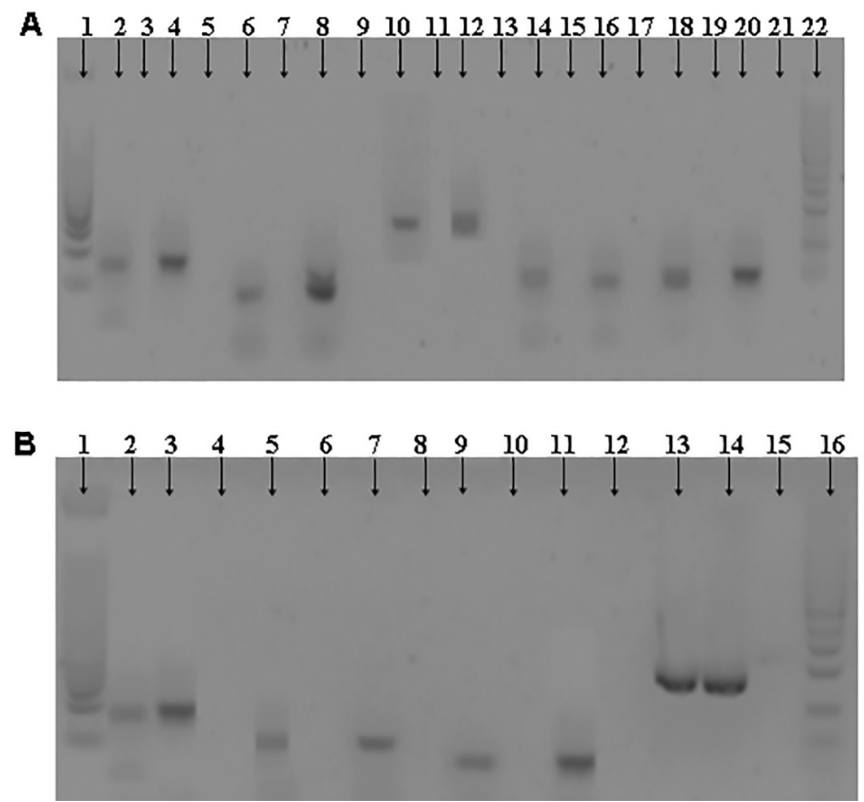

Fig. 4 - Profile of cytokine expression. RT-PCR assays were used for the quantification of mRNA encoding for IL-2, IL-4, IL-6, IL-10, IL-12p35 (3A). 1 = Molecular weight markers (50pb), 2-5 = IL-2 (2: sample positive, 3: sample negative, 4: positive control and 5: negative control), 6-9 = IL-4 (6: sample positive, 7: sample negative, 8: positive control and 9: negative control), 10-13 = IL6 (10: sample positive, 11: sample negative, 12: positive control and 13: negative control), 14-17 = IL-10 (14: sample positive, 15: sample negative, 16: control positive and 17: control negative), 18-21 = IL-12 (18: sample positive, 19: sample negative, 20: control positive and 21: control negative), $22=$ Molecular weight markers (100pb). RT-PCR assays were also used for the quantification of mRNA encoding for IFN- $\gamma$, TNF- $\alpha$, TGF- $\beta$ and $\beta$-actin (3B). 1: Molecular weight markers (50pb), 2-4 = IFN- $\gamma$, (2: sample positive, 3 : control positive and 4: control negative), $5-8=\mathrm{TNF}-\alpha$ (5: sample positive, 6 : sample negative, 7: control positive and 8: control negative), 9-12 = TGF- $\beta$ (9: sample positive, 10: sample negative, 11: control positive and 12: control negative), 13-15 = $\beta$-actin (13: sample positive, 14: control positive and 15: control negative), $16=$ Molecular weight markers $(100 \mathrm{pb})$.
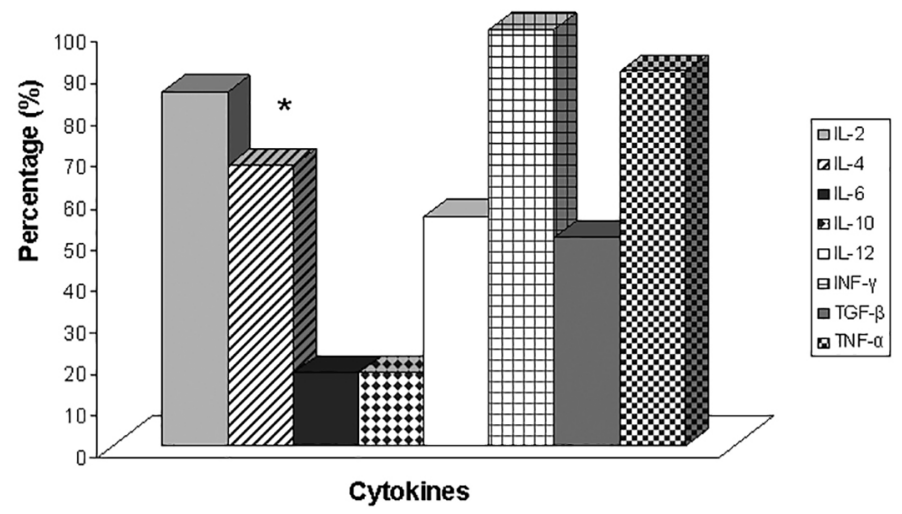

Fig. 5 - Percentage of individuals showing positive expression of cytokine. The percentage

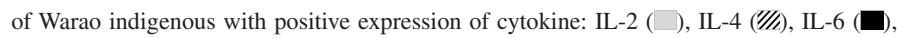

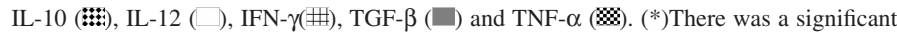
increased expression of the IL-4 in individuals with reactivity IgG to TES antigens $(p<0.002)$.
A serological follow up was carried out in 27 children with toxocariasis, the results showed, that the highest sensitivity of $100 \%$ was reached when the avidity of $T$. canis antibodies $\mathrm{IgG}$ was evaluated using ELISA and $\mathrm{WB}^{12,20,23,42}$. In addition, a study determined the T. canis (TES) seropositivity rate among healthy people with eosinophilia over $10 \%$; the results showed that $67 \%$ were positive to bands sizes of 66,56 , 32 and $13 \mathrm{kDas}$ by WB; while that in ELISA, $65 \%$ of sera were positive to TES antigen ${ }^{15}$. In the present study, $22.2 \%$ and $8.8 \%$ of serum were positive to bands size of $32 \mathrm{kDa}$ and $66 \mathrm{kDa}$, respectively by Western Blot, while that the TES seropositivity obtained by using indirect-ELISA IgG, shows $9.3 \%$ and $14.3 \%$ in indigenous adults and children, respectively. Several reports describe high and low sensitivity of anti-TES IgG method; these different findings can be explained since it has been reported that serum immunoglobulin $\mathrm{G}$ antibodies are produced against a variety of epitopes on the antigen surface and also the number and the species of serologically reactive antigens varied greatly from individual to individual or population to population and the level of specific antibodies could also vary with the age of individuals ${ }^{6,15,33,39}$. In this context, the possible age effect on seropositivity for both of these zoonotic infections was studied. The findings in relation to the age distribution according $A$. suum and $T$. canis seropositivity showed that the trend of seropositivity is similar for both pathogens; however, the A. suum seropositivity is slightly higher (30.8\%) than T. canis seropositivity (25.6\%), especially for the age group of 21-40 years old, both seropositivities were significantly increased as compared to the age groups of 0-10, 11-20 years old and 61 years and older, it was observed that the seropositivity thereafter clearly increases with age, but it decreased for the age group of 61 years and older. Whether A. suum and T. canis transmission for this population is by direct ingestion of contaminated soil remains to be investigated.

On the other hand, in the adult group, $44.1 \%$ were seropositive for both parasites; these results suggest that infection by Toxocara is essentially as common as that by Ascaris; however AES seropositivity in adults and children was shown to be higher; $23.3 \%$ and $57.1 \%$, than TES seropositivity, $9.3 \%$ and $14.3 \%$, respectively. A high Toxocara seropositivity in slum areas of Caracas and El Mojan, Venezuela ${ }^{10,21,22}$ has been reported. Since it is more common to see pigs than dogs in these indigenous communities, a low exposure of children to $T$. canis, could explain the present findings.

As mentioned above, the ELISA based on the use of excretory/ secretory antigens produced by the larvae of the A. suum and T. canis is the most common approach for serodiagnosis; however, the specificity of which can be inadequate in regions of endemic helminthiasis ${ }^{14,32}$. In this context, it was reported that reactivity of sera to AES antigens using the ELISA test was reduced by pre-absorption with extracts of $A$. lumbricoides, a nematode antigenically related to $A$. suum and although this topic is still controversial, the most recent research reports that molecular biology has shown it to be a single species, authors concluded that $A$. lumbricoides and $A$. suum are a single species and that the name A. lumbricoides Linnaeus 1758 has taxonomic priority; therefore $A$. suum Goeze 1782 should be considered a synonym of $A$. lumbricoides ${ }^{19}$, the latter is a common intestinal nematode of Venezuelan children ${ }^{10,21}$. Since Western blotting has been proposed as a confirmatory test for the diagnosis of toxocariosis ${ }^{20}$, this method was performed using AES and TES antigens. For AES antigens, the immunoblotting showed a pattern of bands ranging from 52 to $206.9 \mathrm{kDas}$, with the predominance of the three of these; while that for TES antigens; this pattern of bands was ranging 


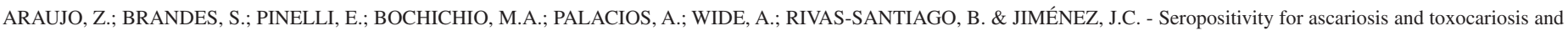
cytokine expression among the indigenous people in the Venezuelan Delta region.. Rev. Inst. Med. Trop. Sao Paulo, 57(1): 47-55, 2015.

from 22.9 to $223 \mathrm{kDas}$; among these 11 major bands were principally identified. It has been reported that bands of high molecular weight principally are responsible for the cross-reactivity between $T$. canis and A. suum; however, authors reported that a band with molecular weight around 55 to $66 \mathrm{kDa}$ is also, at least, responsible for the cross-reactivity between both parasites ${ }^{17,28}$. Concerning, the existence of cross-reactivity among A. suum and T. canis, Western blotting was performed using serum samples from patients with positive result by ELISA. The findings showed the existence of cross-reactivity among A. suum and T. canis, four major bands were principally identified 52.2, $94.1 \mathrm{kDa}, 149 \mathrm{kDa}$, and $193.6 \mathrm{kDa}$. In experimental animals, cross-reactivity between $T$. canis and A. suum has also been reported, so the Western blotting showed that the rat IgG recognized three proteins of 190, 160 and $33 \mathrm{kDas}$ in the antigens from F. hepatica, T. canis and A. suum; the author suggests that the existence of cross-reactivity among these antigens seems to also demonstrate the presence of structural similarities, such as tegumental proteins ${ }^{35}$.

Findings about pre-absorption treatment performing Western blotting technique and using serum samples from individuals with $A$. suum seropositivity showed five bands principally identified; 159.4, $137.8,125.1,29.2$, and $24 \mathrm{kDas}$; whereas when using serum from individuals with $T$. canis seropositivity, four bands were principally identified; 203.1, 152, 144.7, and 131.3 kDas. The available seroprevalence data about AES and TES antigens here analyzed and results about the microscopic examination of stool samples showing that a high prevalence of intestinal parasites among indigenous exist, especially parasites such as Blastocystis hominis, Hymenolepis nana and Entamoeba coli suggesting that further studies must be performed to improve the sensitivity and specificity of the Ascaris and Toxocara ELISA test by pre-absorption with extracts of prevalent parasites among Warao indigenous and more serum samples.

On the other hand, relative quantification of cytokine expressions, Th1 and Th2 in peripheral blood cells from indigenous studied was also evidenced. In Venezuela there are 28 different ethnic groups, Warao are one of them (no persons of mixed race or indigenous), whose socioeconomic status is low; they do not have access to health care compared with the Creole people from the urban areas, Warao individuals also have recurrent or overwhelming parasite infections ${ }^{1}$. Helminth infections are among the most potent stimulators of Th2-type immune responses and have been widely demonstrated to modify responsiveness to both non parasite antigens and other infectious agents in a nonspecific manner in infected animals; the balance of Th1 and Th2 immune responses is known to be crucial for determining both the protective and pathological responses to infections with a variety of pathogens ${ }^{13,16,8}$. In the case of a number of gastrointestinal nematode infections, Th2 responses are generally associated with protection, while Th1 responses are associated with susceptibility ${ }^{8,43}$.

A study showed that $A$. lumbricoides infections in endemic regions are associated with a highly polarized type 2 cytokine response ${ }^{8}$. In addition, a significant association between intestinal helminthic infections and mycobacterial diseases, such as pulmonary tuberculosis and multibacillary leprosy, has been demonstrated by several authors ${ }^{1,7}$. It has been reported that concomitant helminthic infection in patients with diagnosed tuberculosis skews their cytokine profile toward a T helper 2 response ${ }^{7}$. Since that, official data on the tuberculosis situation in Venezuela showed that between 1997 and 2001 the tuberculosis rate was between 93.2 and
81.0 among Warao indigenous population ${ }^{26,27}$. Based on this notion and the significant association between intestinal helminthic infections and mycobacterial diseases mentioned above, studies of relative quantification of cytokine expression were performed; the findings showed that there was only a significant increased expression of the IL-4 in individuals with TES seropositivity $(p<0.002)$, whereas, the expression of the IFN- $\gamma$, IL-2, IL-6, TGF- $\beta$, TNF- $\alpha$, IL-10 and IL-4 transcripts were not different to that of individuals with AES seropositivity. The results of the present study suggest that $T$. canis antigens have a potent immunomodulatory activity and that the effects observed are consistent with skewing towards a Th2-type response rather than induction of Th1-type response. The latter probably due to two syndromes that have been identified, which remain for a long time in the host, the visceral larva migrans syndrome (VLM) and the ocular larva migrans syndrome (OLM $)^{9}$. Importantly, the induction of interleukin- 4 by $T$. canis antigens also suggests that $\mathrm{T}$ cells may play a role in immunomodulation of immune responses by parasitic helminths that result in a dominant Th2 type of the immune response. While this presumably promotes parasite survival, it may markedly impair protective immune responses to Mycobacterium tuberculosis infection. Further studies are needed to understand the association between helminthic infections such as A. suum and T. canis and a dominant Th2 cytokine profile in Warao indigenous, which could favor persistent $M$. tuberculosis infection in this population. Finally, the immunoblotting and ELISA techniques may constitute useful methods for the diagnosis of the zoonoses infections like ascariosis or toxocariosis, which are prevalent among Warao indigenous. In addition, measures to control these helminthic infections are recommended.

\section{RESUMEN}

\section{Seropositividad para ascariosis y toxocariosis y expresión de citocinas entre la población indígena de la región del delta Venezolano}

El objetivo del presente estudio fue determinar la seropositividad de infección por Ascaris suum y Toxocara canis, utilizando antígenos de excreción/secreción (E/S) de Ascaris suum (AES) y Toxocara canis (TES) en una población indígena. Adicionalmente, se cuantificó la expresión de citocinas a partir de células de sangre periférica. Un total de 50 indígenas Warao se incluyeron en el estudio; 43 fueron adultos y 7 niños. Entre los adultos, $44,1 \%$ fueron seropositivos para ambos parásitos; mientras que los niños sólo mostraron seropositividad a uno u otro de los helmintos. Para ascariosis, el porcentaje de seropositividad para los antígenos AES fue alto tanto en adultos como en niños; $23,3 \%$ y $57,1 \%$, respectivamente. Para toxocariosis, el porcentaje de seropositividad para los antígenos TES fue bajo en adultos así como en niños; $9,3 \%$ y 14,3\%, respectivamente. El porcentaje de seronegatividad fue similar tanto para los antígenos AES como para TES en adultos $(27,9 \%)$ y niños $(28,6 \%)$. Cuando la seropositividad fue analizada a través de la técnica de Western blotting utilizando los antígenos AES; 3 bandas de 97,2, 193,6 y 200,2 kDas fueron principalmente reconocidas. Para los antígenos TES, 9 bandas fueron mayormente identificadas; 47,4, 52,2, 84,9, 98,2, 119,1, 131,3, 175,6, 184,4 y 193,6 kDas. Los análisis coproparasitológicos mostraron que los parásitos Blastocystis hominis, Hymenolepis nana y Entamoeba coli fueron los parásitos intestinales más comúnmente observados. La cuantificación de la expresión de las citocinas IFN- $\gamma$, IL-2, IL-6, TGF- $\beta$, TNF- $\alpha$, IL-10 e IL-4 mostró que hubo un significante incremento de la expresión de IL-4 entre los indígenas con seropositividad para los 
ARAUJO, Z.; BRANDES, S.; PINELLI, E.; BOCHICHIO, M.A.; PALACIOS, A.; WIDE, A.; RIVAS-SANTIAGO, B. \& JIMÉNEZ, J.C. - Seropositivity for ascariosis and toxocariosis and cytokine expression among the indigenous people in the Venezuelan Delta region.. Rev. Inst. Med. Trop. Sao Paulo, 57(1): 47-55, 2015.

antígenos TES $(p<0.002)$. La seropositividad para Ascaris y Toxocara fue prevalente entre los indígenas Warao.

\section{ACKNOWLEDGEMENTS}

This study was supported by Consejo de Desarrollo Humanístico y Científico de la Universidad Central de Venezuela, Projects No. CDCH/ UCV-PG 09-8007-11/AIA-09-8397-12).

\section{REFERENCES}

1. Araujo Z, Fernández de Larrea C, López D, Fandiño C, Chirinos M, Convit J, et al. Hematologic values among Warao indians with tuberculosis from the Orinoco delta of Venezuela. Acta Cient Venez. 2003;54:247-53.

2. Arizono N, Yoshimura Y, Tohzaka N, Yamada M, Tegoshi T, Onishi K, et al. Ascariasis in Japan: is pig-derived Ascaris infecting humans? Jpn J Infect Dis. 2010;63:447-8.

3. Bach-Rizzatti BC. Desenvolvimento de teste imunoenzimático, ELISA, para o diagnóstico da toxocaríase humana. [dissertação]. São Paulo: Universidade de São Paulo, Faculdade de Ciências Farmacêuticas; 1984

4. Bundy DA. Immunoepidemiology of intestinal helminthic infections. 1. The global burden of intestinal nematode disease. Trans R Soc Trop Med Hyg. 1994;88:259-61.

5. Camargo ED, Nakamura PM, Vaz AJ, da Silva MV, Chieffi PP, de Melo EO. Standardization of dot-ELISA for the serological diagnosis of toxocariasis and comparison of the assay with ELISA. Rev Inst Med Trop S Paulo. 1992;34:55-60.

6. Delgado O, Rodríguez-Morales AJ. Aspectos clínicos-epidemiológicos de la toxocariasis: una enfermedad desatendida en Venezuela y América Latina. Bol Malar Salud Amb. 2009;49:1-33.

7. Elias D, Mengistu G, Akuffo H, Britton S. Are intestinal helminths risk factors for developing active tuberculosis? Trop Med Int Health. 2006;11:551-8.

8. Else KJ, Finkelman FD, Maliszewski CR, Grencis RK. Cytokine-mediated regulation of chronic intestinal helminth infection. J Exp Med. 1994;179:347-51.

9. Feldman GJ, Parker HW. Visceral larva migrans associated with the hypereosinophilic syndrome and the onset of severe asthma. Ann Int Med. 1992;116:838-40.

10. Garcia Pedrique ME, Díaz Suárez O, Estevez J, Cheng-Ng R, Araujo-Fernández M, Castellano J, et al. Prevalencia de infección por Toxocara en pre-escolares de una comunidad educativa de El Mojan, estado Zulia, Venezuela. Invest Clin. 2004;45:34754.

11. Glickman LT, Schantz PM. Epidemiology and pathogenesis of zoonotic toxocariasis. Epidem Rev. 1981;3:230-50.

12. Jin Y, Shen C, Huh S, Sohn WM, Choi MH, Hong ST. Serodiagnosis of toxocariasis by ELISA using crude antigen of Toxocara canis larvae. Korean J Parasitol. 2013;51:433-9.

13. Kayes SG, Oaks JA. Effect of inoculum size and length of infection on the distribution of Toxocara canis larvae in the mouse. Am J Trop Med Hyg. 1976;25:573-80.

14. Kennedy MW, Tomlinson LA, Fraser EM, Christie JF. The specificity of the antibody response to internal antigens of Ascaris: heterogeneity in infected humans, and MHC (H-2) control of the repertoire in mice. Clin Exp Immunol. 1990;80:219-24.

15. Kim YH, Huh S, Chung YB. Seroprevalence of toxocariasis among healthy people with eosinophilia. Korean J Parasitol. 2008;46:29-32.

16. King CL, Kumaraswami V, Poindexter RW, Kumari S, Jayaraman K, Alling DW, et al. Immunologic tolerance in lymphatic filariasis. Diminished parasite-specific $\mathrm{T}$ and B lymphocyte precursor frequency in the microfilaremic state. J Clin Invest. 1992;9:1403-10.
17. Laemmli UK. Cleavage of structural proteins during the assembly of the head of bacteriophage $\mathrm{T}_{4}$. Nature. 1970;227:680-5.

18. Lescano SA, Nakhle MC, Ribeiro MC, Chieffi PP. IgG antibody responses in mice coinfected with Toxocara canis and other helminthes or protozoan parasites. Rev Inst Med Trop Sao Paulo. 2012;54:145-52.

19. Leles D, Gardner SL, Reinhard K, Iñiguez A, Araujo A. Are Ascaris lumbricoides and Ascaris suum a single species? Parasit Vectors. 2012;5:42-9.

20. Lopez MA, Bojanich MV, Alonso ME, Alonso JM. Immunoblotting para diagnóstico de toxocarosis humana en un área subtropical. Parasitol Latinoam. 2005;60:127-31.

21. Lynch NR, Hagel I, Vargas V, Rotundo A, Valera MC, Di Prisco MC, et al. Comparable seropositivity for ascariosis and toxocariasis in tropical slum children. Parasitol Res. 1993;7:547-50.

22. Lynch NR, Wilkes LK, Hodgen AN, Turner KJ. Specificity of Toxocara ELISA in tropica populations. Parasite Immunol. 1988;10:323-37.

23. Magnaval JF, Fabre R, Mauriéres P, Charlet JP, de Larrard B. Application of the Western blotting procedure for the immunodiagnosis of human toxocariasis. Parasitol Res. 1991;77:697-702.

24. Maizels RM, Savigny DH, Ogilvie BM. Characterization of surface and excretorysecretory antigens of Toxocara canis infective Larvae. Parasite Immunol. 1984;6:2337.

25. Mendonça RL, Veiga RV, Dattoli VC, Figueredo CA, Fiaccone R, Santos J, et al. Toxocara seropositivity, atopy and wheezing in children living in poor neighbourhoods in urban Latin American. PLOS Negl Trop Dis. 2012;6:e1886.

26. Ministerio de Salud y Desarrollo Social. Evaluación del programa nacional de control de la tuberculosis. Año evaluado 2001. Caracas: MSDS; 2002.

27. Ministerio de Sanidad y Asistencia Social. Seminario técnico-administrativo. Programa integrado de control de la tuberculosis. Caracas: MSAS; 1999.

28. Nejsum P, Parker ED Jr, Frydenberg J, Roepstorff A, Boes J, Haque R, et al. Ascariasis is a zoonosis in Denmark. J Clin Microbiol. 2005;43:1142-8.

29. Nunes CM, Tundisi RN, Garcia JF, Heinemann MB, Ogassawara S, Richtzenhain LJ. Cross-reactions between Toxocara canis and Ascaris suum in the diagnosis of visceral larva migrans by Western blotting technique. Rev Inst Med Trop Sao Paulo. 1997;39:253-6.

30. Obwaller A, Jensen-Jarolim E, Auer H, Huber A, Kraft D, Aspock H. Toxocara infestations in humans: symptomatic course of toxocarosis correlates significantly with levels of IgE/anti-IgE immune complexes. Parasite Immunol. 1998;20:311-7.

31. Okada F, Ono A, Ando Y, Yotsumoto S, Yotsumoto S, Tanoue S, et al. Pulmonary computed tomography findings of visceral larva migrans caused by Ascaris suum. J Comput Assist Tomogr. 2007;31:402-8.

32. Paterson JCM, Garside P, Kennedy MW, Lawrence CE. Modulation of a heterologous immune response by the products of Ascaris suum. Infect Immun. 2002;70:6058-67.

33. Pinelli E, Herremans T, Harms MG, Hoek D, Kortbeek LM. Toxocara and Ascaris seropositivity among patients suspected of visceral and ocular larva migrans in the Netherlands: trends from 1998 to 2009. Eur J Clin Microbiol Infect Dis. 2011;30:8739.

34. Petithory JC. Can Ascaris suum cause visceral larva migrans? Lancet. 1996;348(9028):689.

35. Romasanta A, Romero JL, Arias M, Sánchez-Andrade R, López C, Suárez JL, et al Diagnosis of parasitic zoonoses by immunoenzymatic assays-analysis of crossreactivity among the excretory/secretory antigens of Fasciola hepatica, Toxocara canis, and Ascaris suum. Immunol Invest. 2003;32:131-42. 


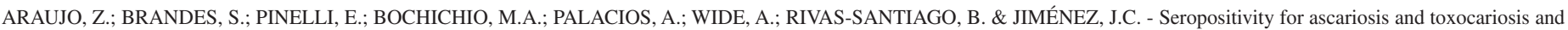
cytokine expression among the indigenous people in the Venezuelan Delta region.. Rev. Inst. Med. Trop. Sao Paulo, 57(1): 47-55, 2015.

36. Rubinsky-Elefant G, Hoshino-Shimizu S, Arroyo-Sanchez MC, Abe-Jacob CM, Ferreira AW. A serological follow-up of toxocariasis patients after chemotherapy based on the detection of $\operatorname{IgG}, \operatorname{IgA}$, and IgE antibodies by enzyme-linked immunosorbent assay. J Clin Lab Anal. 2006;20:164-72.

37. Savigny DH. In vitro maintenance of Toxocara canis larvae and a simple method for the production of Toxocara ES antigen for use in serodiagnostic tests for visceral larva migrans. J Parasitol. 1975;61:781-2.

38. Schantz PM. Toxocara larva migrans now. Am J Trop Med Hyg. 1989;41(3 Suppl):21-34

39. Speiser F, Gottstein B. A collaborative study on larval excretory/secretory antigens of Toxocara canis for the immunodiagnosis of human toxocariasis with ELISA. Acta Trop. 1984;41:361-72.

40. Sugane K, Oshima AT. Interrelationship of eosinophilia and IgE antibody production to larval ES antigen in Toxocara canis-infected mice. Parasite Immunol. 1984;6:409-20.

41. Taylor MR, Keane CT, O'Connor P, Mulvihill E, Holland C. The expanded spectrum of Toxocara disease. Lancet. 1988;26(8587):692-5.
42. Towbin H, Staehelin T, Gordon J. Electrophoretic transfer of proteins from polyacrilamyde gels to nitrocellulose sheets: procedure and some applications. Proc Natl Acad Sci USA. 1979;76:4350-4.

43. Urban JF Jr, Madden KB, Cheever AW, Trotta PP, Katona IM, Finkelman FD. IFN inhibits inflammatory responses and protective immunity in mice infected with the nematode parasite Nippostrongylus brasiliensis. J Immunol. 1993;151:7086-94.

44. World Health Organization. Prevention and control of schistosomiasis and soil-transmitted helminthiasis. Geneva: World Health Organization; 2002. (Technical Report Series, No. 912).

45. World Health Organization. Intestinal protozoan and helminthic infections. Geneva: World Health Organization; 1981. (Technical Report Series, No. 666).

Received: 10 February 2014

Accepted: 26 May 2014 